\title{
Temporal Bone Meningocele Presenting as a Pulsatile Mass of the External Auditory Canal
}

\author{
Jang-Won Jeong and Eun-Ju Jeon \\ Department of Otolaryngology, The Catholic University of Korea College of Medicine, Incheon St. Mary's Hospital, Incheon, Korea
}

\section{박동성 외이도 종물로 나타난 측두골 수막류 1예}

\author{
정 장 원·전 은 주 \\ 가톨릭대학교 의과대학 인천성모병원 이비인후과학교실
}

\author{
Received August 6, 2015 \\ Revised November 10, 2015 \\ Accepted November 17, 2015 \\ Address for correspondence \\ Eun-Ju Jeon, MD \\ Department of Otolaryngology, \\ The Catholic University of Korea \\ College of Medicine, \\ Incheon St. Mary's Hospital, \\ 56 Dongsu-ro, Bupyeong-gu, \\ Incheon 21431, Korea \\ Tel $+82-32-280-5877$ \\ Fax $+82-32-280-5914$ \\ E-mail ejmercy@catholic.ac.kr
}

Meningocele is a protrusion of meninges through a defect in the skull base. It is a rare but potentially life-threatening condition requiring surgery. We present a case of 59-year-old woman complaining of persistent otorrhea of the right ear and a pulsating cystic mass occupying the external auditory canal in her right ear. The patient had undergone right canal wall up mastoidectomy and tympanoplasty about 30 years ago. Radiological evaluations revealed a bony defect at the tegmen tympani and tegmen mastoideum, with a cystic mass filling this defect and the external auditory canal, suggesting temporal bone meningocele. The meningocele was resected and the bony defect of tegmen was successfully repaired via combined transmastoid and middle cranial fossa mini-craniotomy approach.

Korean J Otorhinolaryngol-Head Neck Surg 2016;59(5):396-401

Key Words External auditory canal $\cdot$ Meningocele $\cdot$ Temporal bone.

\section{서 론}

수막류는 두개골의 결손 부위를 통해 수막이 돌출되는 것 을 말하며 뇌조직이 같이 돌출될 시에 수막뇌류라고 한다. ${ }^{1)}$ 측두골에는 드물게 발생하고, 대부분 중이강이나 유양동으 로 돌출되는 종괴 양상으로 나타나는 것으로 알려져 있으며, 외이도 종물로 나타나는 경우는 가성 수막류의 형태로 전 세 계적으로 2예 보고되어 있다.,3)

측두골 수막류의 증상과 징후는 무증상에서부터 청력감 소, 만성 이루, 이명, 어지럼까지 다양하게 나타날 수 있으며, 더 진행되는 경우 뇌척수액 이루 혹은 비루, 경련, 발작, 수막염, 뇌농양 등의 심각한 합병증이 발생할 수 있고, 드물게 사망에 이를 수 있기에 수술적 교정이 필요하다. ${ }^{4)}$ 대부분의 측두골 수막류는 유양동 삭개술과 같은 이과적 수술이나 외상 후에 발생하는 것으로 알려져 있으며, 그 외에 진주종성 혹은 비진 주종성 만성 중이염, 선천성 두개저 결손, 종양, 방사선치료 등
이 원인이 되기도 한다.,6)

저자들은 30년 전 중이염 수술을 받은 기왕력이 있는 환자 에서 외이도 박동성 종물로 나타난 수막류를 진단하고 수술 적 치료로 완치된 1 예를 경험하였기에 문헌 고찰과 함께 보고 하는 바이다.

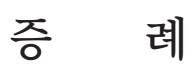

59세 여자 환자가 10일 전부터 발생한 좌측 이통과 이루 및 30 여 년 전 우측 이과 수술 후의 상태 확인을 위해 내원하였 다. 타 병원에서 우측 이과 수술을 시행받은 후 우측의 간헐 적인 이루가 있어 왔으나, 경도의 난청 외에 특별한 증상이 없 어 적극적인 치료는 하지 않고 지냈고, 10 년 전부터 간헐적인 좌측 만성 이루 및 점진적인 난청을 호소하였다. 기타 과거력 으로 15 년 전에 좌측 두정엽 뇌수막종을 진단받고, 개두술을 통한 종양절제술을 시행받았으며, 개두술 이후 간헐적인 경련 
증상이 발생하여 지속적으로 항경련제 약물을 복용하는 중 이었다. 이명이나 이충만감은 양측 귀 모두 없다고 하였고 어 지럼도 없었다. 이학적 검사상 우측 외이도 후상방에서 시작 되는 박동성 종물이 골-연골 접합부 내측에서 시작하여 외 이도를 전부 차지하고 있었고, 고막은 종물로 인하여 관찰할 수 없었다(Fig. 1). 발살바 수기(Valsalva maneuver)를 시키자 종물의 크기가 약간 커지면서 박동 양상이 더 뚜렷해지는 것 을 관찰할 수 있었다. 좌측 귀는 고막 후방부 천공과 맑은 분 비물이 관찰되었다. 순음청력검사상 평균 기도/골도 역치는 오

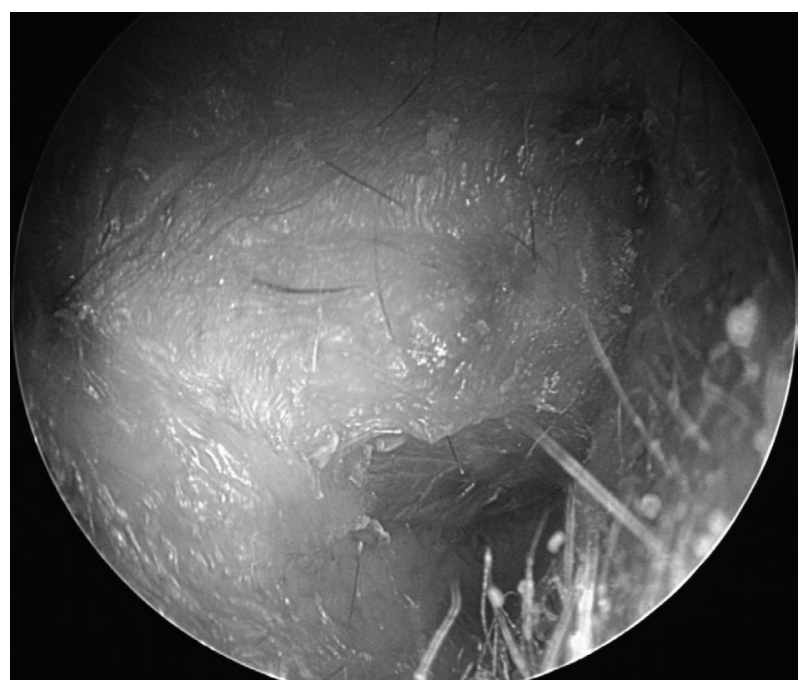

Fig. 1. Preoperative findings of right external auditory canal. Pulsatile mass originating from posterior-superior wall is occupying external auditory canal and obscuring tympanic membrane.
른쪽 $60 / 30 \mathrm{~dB}$, 왼쪽 $50 / 35 \mathrm{~dB}$ 로 양측 혼합성 난청 소견을 보였다(Fig. 2A). 우측 수막뇌류 의증 및 좌측 만성 중이염에 대한 평가를 위해 측두골 컴퓨터단층촬영 및 자기공명영상 검사를 시행하였다. 우측 측두골에 상반고리관 후방부터 시 작되는 중두개와의 골결손이 있고, 골결손 부위를 통해 뇌척 수액을 포함하는 낭성 종물이 형성되어, 유양동 삭개술을 시 행받은 흔적으로 생각되는 공동 부위를 채우고 있었고, 종 물은 전방으로 진행하여 외이도 후벽을 파괴하며 외이도로 돌출되고 있었다. 외이도로 돌출된 종물은 고막 외측 표면에 접촉하면서 고막을 내측으로 압박하여 고막이 침등골 관절과 유착되어 있었으나 중이강은 침범하지 않고 비교적 건강하게 유지되고 있었다. 조영증강영상에서 종물의 내부는 뇌척수액 과 같은 음영을 보이고, 뇌 실질은 포함하지 않아 수막류로 의 심할 수 있었다(Fig. 3).

우선적으로 우측 수막류의 제거 및 골결손 부위의 보강을 위해 수술로서 교정하기로 결정하였고, 좌측 만성 중이염에 대한 치료는 우측 수술 후 6개월째에 수술적 치료를 시행하 기로 계획하였다. 우측 후이개 접근법으로 피부 및 피하조직 을 절개하고 골막을 거상하여 종물을 노출시키고 외이도 피 부와 고막으로부터 종물을 박리하였다. 고막의 후상방은 함 몰되어 등골의 머리부와 고막이 접촉된 양상이었고, 천공은 없었다. 술 전 청력검사에서 혼합성 난청이 있었으나, CT 상 중 이강 내부에 종물의 침습이 없고, 잘 보존되어 있어서 청력검 사상 기도/골도 차는 종물의 외이도 폐쇄 및 고막의 압박에 의한 것으로 생각되었으며, 그러므로 종물을 제거하면 청력
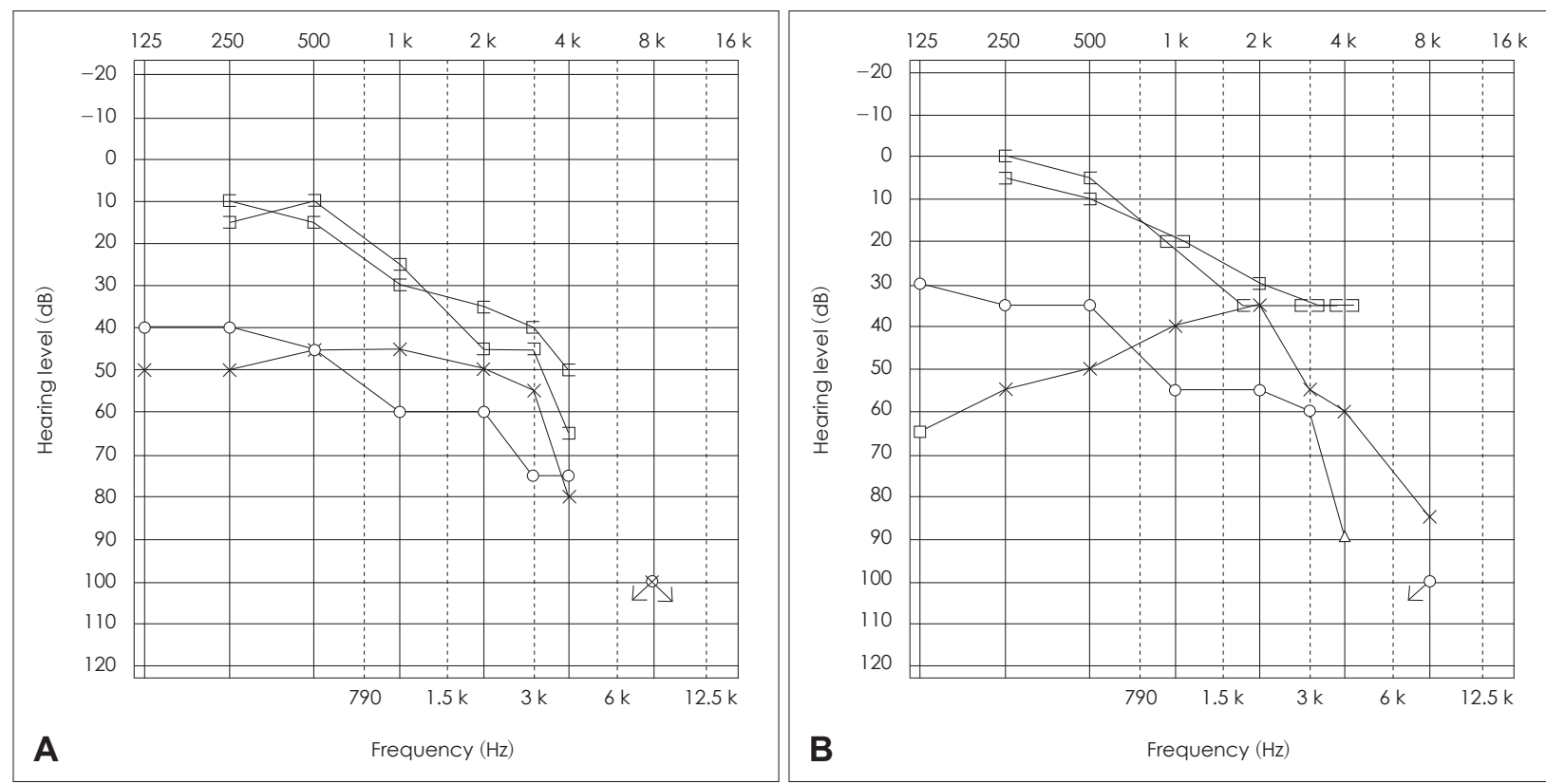

Fig. 2. Preoperative and postoperative pure tone audiogram. Preoperative audiogram shows a mixed hearing loss in the right ear with average threshold of $60 \mathrm{~dB}(\mathrm{~A})$. Three months after surgery, average threshold of the air conduction in the right ear improved to $50 \mathrm{~dB}(\mathrm{~B})$. 
호전이 될 것으로 예상되어 중이 개방 및 이소골 성형술은 시 행하지 않았다. 개방형 유양동 삭개술을 시행하여 유양동에 서 수막류를 박리하고, 배상형성술(saucerization)을 시행하 고 외이도와 유양동에서 박리된 수막류를 양극성 전기소작 기를 이용하여 소작하고 절제한 후 중두개와의 골결손부의 크기를 측정하였는데, $10 \times 5 \mathrm{~mm}^{2}$ 이상의 골결손을 확인할
수 있었다. 신경외과에서 중두개와에 최소 개두술을 통해 측 두엽을 거상하여 경막의 수막류 형성부를 확인하고 양극성 전 기소작기로 소작한 후경막의 결손이 없음을 확인하였고, 중 두개와의 골결손 부위(Fig. 4A)는 Medpore ${ }^{\circledR}($ Stryker, Kalamazoo, MI, USA)를 이용하여 보강하였다(Fig. 4B). 유양동 쪽 에서 자가 연골, 골분 및 측두근막을 이용하여 골결손 부위를
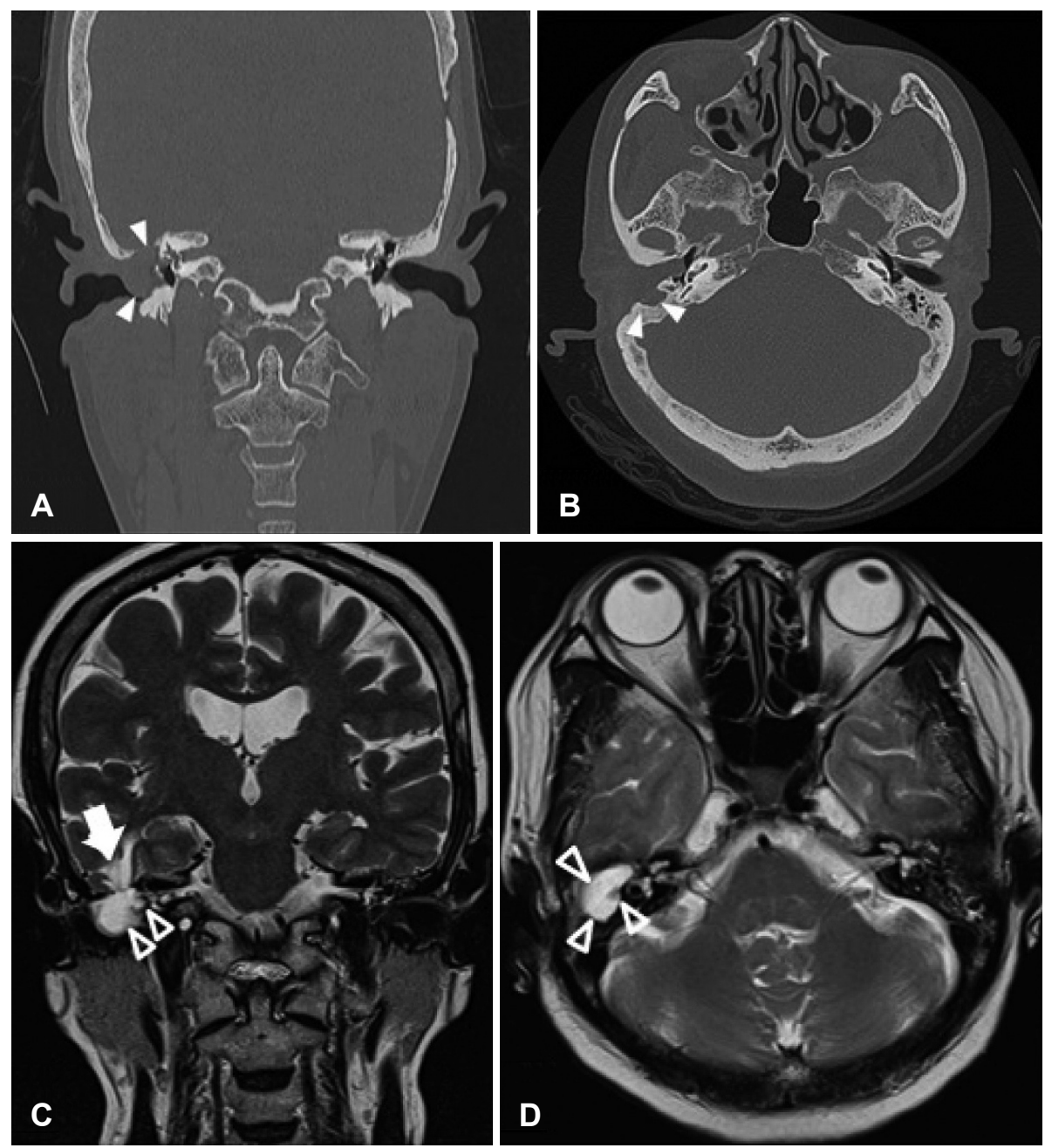

Fig. 3. Temporal bone CT and MRI images of temporal bone meningocele. CT images show bony defect of external auditory canal and tegmen mastoideum. Soft-tissue mass in right external auditory canal and mastoid cavity is in continuity with a tegmental bony defect (white arrowhead) ( $A$ and $B$ ). In T2-weighted images of MRI, connection between meningocele (empty arrowhead) and CSF space (white arrow) is clearly seen $(C$ and $D)$.
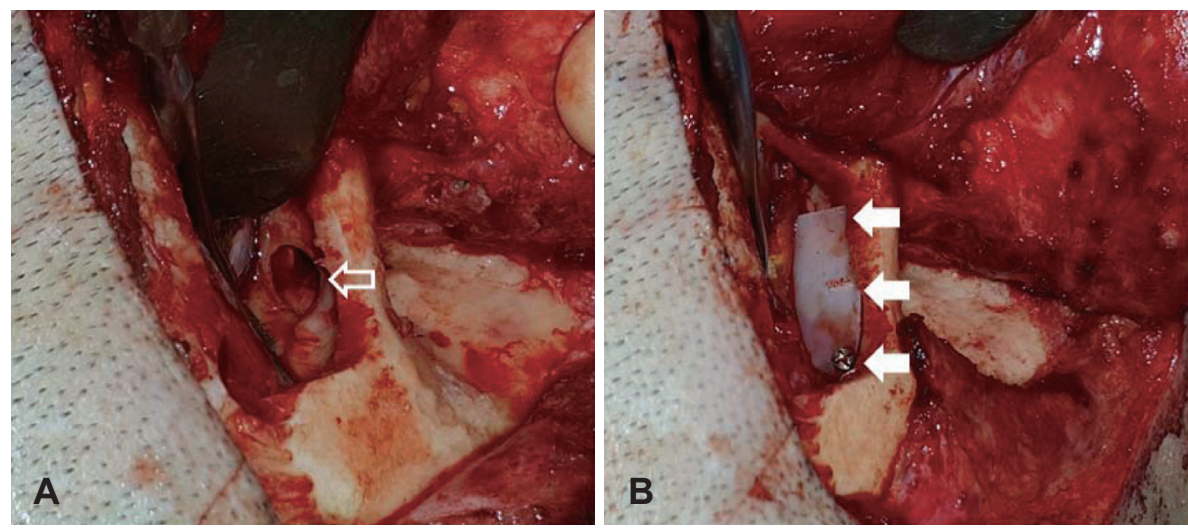

Fig. 4. Bony defect at tegmen mastoideum of which size over than 1 $\mathrm{cm}^{2}$ (empty arrow) (A). Tegmental bony defect was repaired using Medpore $^{\circledR}$ (white arrows) inserted via middle cranial fossa approach (B). 
보강한 후, 측두근 회전 피판을 도안하여 골결손 부위를 추 가로 보강하고, Gelfoam ${ }^{\circledR}$ (Pfizer, New York, NY, USA)과 Furacin 거즈로 유양동 및 외이도를 채우고 수술을 마쳤다.

수술 후 3일간 절대 안정 및 두부 30도 거상을 교육하고, 귀 와 측두부를 덮는 압박 드레싱을 2일간 시행하였다. 수술 후 1 병일째 시행한 뇌 컴퓨터단층촬영에서, 우측 중두개와에 경 도의 기뇌증과 뇌실질 부종이 관찰되었으나 뇌출혈이나 뇌막 류의 잔존조직은 관찰되지 않았다(Fig. 5A). 수술 후 2주 동 안 매일 ceftriaxone $2 \mathrm{~g}$ 을 정맥 주사하였고, 7병일째 추적 뇌 컴퓨터단층촬영 영상에서 기뇌증의 확연한 감소와 함께 부 종이 호전된 것을 확인하고(Fig. 5B), 9병일째 봉합사를 제거 하였으며, 14 병일째 특별한 합병증 없이 퇴원하였다. 종물의 병리조직검사상 뇌 실질은 발견되지 않았고, 부식된 석회화 가 함유된 섬유아교질 조직으로 수막류를 시사하는 결과였 다. 수술 후 3 개월째 시행한 순음청력검사상 기도/골도 역치 는 50/30 dB이었고(Fig. 2B), 6개월째 시행한 측두골 컴퓨터 단층촬영 영상에서 수막류의 재발이 없고, 골결손 부위는 이 식물로 잘 보강되어 있음을 확인하였다(Fig. 6A). 그러나 수 술 후 유양동, 외이도, 고막의 상피화가 느리고 불완전하여 고막 표면이 비후되고 분비물이 상당기간 지속되었는데, 이는 수막류에 의해 외이도 피부벽이 파괴되면서 정상 외이도 피부 층이 전방 $1 / 4$ 에서만 남아 있었던 것이 원인으로 생각된다. 8 개 월째 추적 고실내시경 검사에서 고막과 외이도 벽은 잘 유지 되고 있었고 뇌척수액의 유출이나 염증소견 없이 양호한 상 태를 유지하고 있다(Fig. 6B).

\section{고 찰}

측두골 수막류는 두개골의 골결손을 통해 수막 조직이 중 이나 유양동으로 탈출되는 상태를 말한다. 대개 고실 천장이 나 유양동 천장에 골결손 부위가 발생하면 뇌척수액의 반복 적인 박동, 두개 내 혈압의 변화, 지속적 염증 반응, 이소성 지 주막과립 등의 반응으로 경막이 얇아지면서 수막이나 뇌조직 이 탈출하면서 형성되는 것으로 생각되고 있다. ${ }^{7}$ 골결손을 일 으킬 수 있는 요인으로는 유양동 삭개술의 과거력, 두부외상, 뇌수막염 병력, 진주종 혹은 급성 중이염, 선천성 골결손 등 이 있다. Arìstegui 등ㅎㅇㅔ 따르면 의인적 요인 중 유양동 삭개 술의 과거력이 59 77\%를 차지한다고 하였고, Ramalingam 등 ${ }^{9}$ 은 만성 중이염으로 재수술을 시행한 963 명의 환자 중 13 명에서 뇌 혹은 수막의 탈출이 있었고, 이 중 $92.3 \%$ 가 중두개 와 골결손을 통한 수막뇌류였으며 오직 1 명에서만 후두개와 의 골결손에 의한 수막뇌류였다고 보고하였다. 본 증례의 환 자는 정확한 정보는 없으나, 측두골 컴퓨터단층촬영 결과로 볼 때, 과거에 우측 폐쇄형 유양동 삭개술 및 고실성형술을 시 행받았던 것으로 추정되며, 수술로 인해 유돌개(tegmen mastoideum)에 직접적인 결손이 발생했었거나, 유돌개가 얇아져 있는 상태에서 만성적인 염증 반응이나 뇌척수액의 박동성 압 박이 골부식을 야기하여 골결손을 일으켰을 것으로 생각된다. 측두골 수막뇌류는 전음성 난청 및 혼합성 난청, 이루, 뇌 척수액 누출, 어지럼, 수막염 혹은 경련, 이충만감, 박동성 이 명, 안면마비 등의 증상을 초래할 수 있다. Sanna 등이은 133
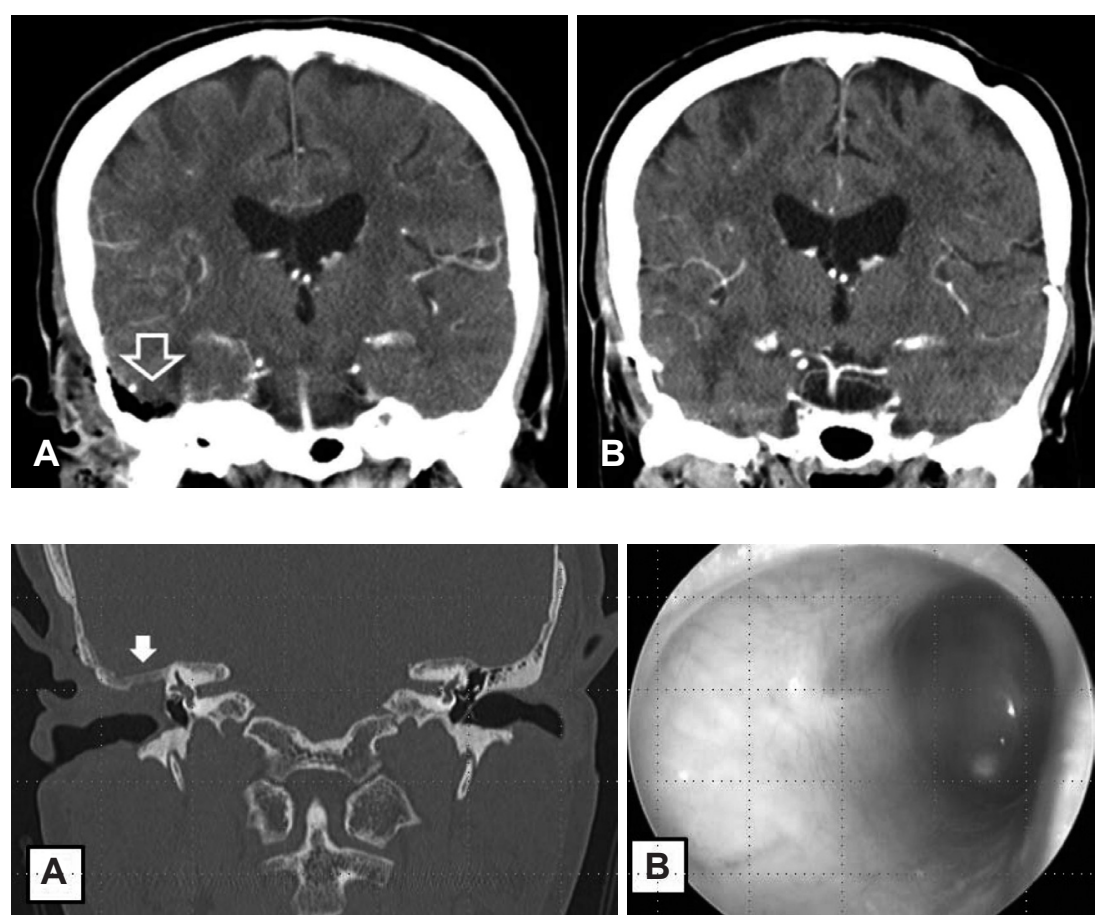

Fig. 6. Postoperative findings. Coronal section of temporal bone CT taken 6 months after operation shows repaired defect at tegmen mastoideum (white arrow) (A). Otoscopic finding of right external auditory canal at 8-months postoperative period (B). Mastoidectomized cavity is intact and there was no evidence of recurrence of meningocele. However, epithelialization has not been completed and the tympanic membrane looks slightly edematous with some discharge. 
명의 측두골 수막뇌류/수막류 증례를 분석하여 임상 양상을 보고한 바 있는데, 이들에 따르면 가장 흔한 증상은 전음성 및 혼합성 난청으로 총 116 명에게서 확인할 수 있었고, 박동성 이 명, 안면마비, 두통 등의 증상을 호소하는 경우는 드물었다. 본 증례의 환자는 수막류가 있던 귀에 간헐적인 이루와 혼합 성 난청 이외에 특별히 호소하는 증상은 없었는데, 이는 원래 중이염으로 난청이 있던 상태였고, 수막류가 외이도 쪽으로 돌 출하면서 중이강은 보존되어 있었기에 기존의 난청 이외에 뚜 렷한 이과적 증상을 느끼지 않았던 것으로 생각된다. Sanna 등이이 증례 보고에서 분석한 133 명 중 외이도 종물이 주증 상인 경우는 없었으나 수술소견상 2 명 $(1.5 \%)$ 에서 외이도 벽의 골결손이 있었다고 하였고, 이는 유양동으로 돌출된 수막뇌류 가 외이도 후벽을 압박 괴사하여 골결손을 유발한 것으로 생 각되며, 이 두 증례가 본 증례처럼 외이도 골결손을 통해 외이 도로 돌출되어 외이도 종물 형태를 취했는지에 대해서는 추 가적인 기술이 없어서 알 수 없으나, Kapusuz 등이이 그들의 증 례 보고에서 언급하였듯이 측두골(가성) 수막뇌류가 외이도 종물로 돌출되는 경우는 흔치 않은 것으로 생각된다.

측두골 수막뇌류/수막류의 빠르고 정확한 진단을 위해서 는 이전에 수술이나 외상의 기왕력이 있는 환자에서 유양동이 나 외이도 쪽으로 돌출된 종물이 있을 때에 미리 가능성을 의심해보는 자세가 필요하며, 확진을 위해서는 고해상도 측 두골 전산화단층촬영과 자기공명영상검사가 필요하다. 수막 뇌류/수막류의 경우 측두골 전산화단층촬영 검사에서 경계 가 분명한 연부 조직 음영이 중두개와의 골결손을 통해 연결 되는 것을 관찰할 수 있다. 그러나 수막뇌류/수막류를 진주 종이나 육아조직, 콜레스테롤 육아종, 연부조직 종양 등과 구분하기 위해서는 자기공명검사를 시행하여 T1, T2 강조영 상에서 뇌척수액이나 뇌실질과 같은 신호강도를 보이고 조영 제에 조영 증강되지 않으며 고실 천장 결손과 이어지는 것을 관찰해야 한다. ${ }^{11}$ 수막뇌류와 수막류의 감별점으로는 수막뇌 류는 고실 천장 결손과 이어지는 병변이 뇌실질과 같은 신호 강도를 보이고, 수막류는 T1, T2 영상에서 뇌척수액과 같은 신호 강도를 보이고 조영제에 증강되지 않는다. ${ }^{1)}$

탈출된 뇌 및 수막 조직은 임상적으로 뇌척수액 누출, 간 질, 두개 내 염증 등 심각한 합병증을 일으킬 수 있으므로 임 상 양상과 영상 검사상 수막뇌류/수막류가 의심되면 수술적 인 치료가 필요하다. 수술적 접근의 결정에 대해서 Sanna 등이 은 발병 원인, 골결손의 위치와 크기, 수술 전 청력 상태, 중이 강의 감염 유무, 수술 중 뇌척수액의 누출 여부를 고려하여 결정하여야 한다고 하였으며, 경유양동 접근법, 중두개와 접 근법, 복합 접근법, 중이 폐쇄술의 4가지 방법 중 선택할 수 있다고 보고한 바 있다. 경유양동 접근법은 유양동을 통해
골결손 부위에 연골 조각을 보강하는 방법으로 중두개와의 결손이 작고 단일하며 유돌개에 국한되어 있고, 이소골이 침범 되지 않은 경우에 사용할 수 있다. 중두개와 접근법은 측두골 표면에 최소 개두술을 시행하고 측두엽을 거상하여 골결손 을 보강하는 방법으로서, 중이강의 병변이 없는 자발성 측두 골 수막뇌류에서 사용할 수 있으며 이소골 손상의 위험성을 최소화할 수 있다는 장점이 있다. 복합 접근법은 중이강에 병 변이 있으면서 골결손 크기가 큰 경우에 경유양동법과 중두 개와 접근법을 복합하여 수술하는 방법이다. 위의 세 가지 방 법으로 접근과 복구가 불가능할 정도로 피부 결손이 심하거 나 고도 난청이 있는 경우, 혹은 1 차 재건 수술 후 재발한 경우 에는 외이도 결찰 및 중이 폐쇄술을 사용하게 된다. ${ }^{10)}$

Sanna 등 ${ }^{12)}$ 은 최근 측두골 수막뇌류에 대한 수술적 접근 법에 대해 골결손과 탈출 조직의 크기를 위주로 결정하는 새 로운 방법을 제시하고 있는데, 이에 따르면 골결손의 크기가 $10 \mathrm{~mm}$ 미만 또는 탈출 조직의 크기가 $1 \mathrm{~cm}^{2}$ 미만이면 경유양 동 접근법으로, 골결손의 크기가 $10 \mathrm{~mm}$ 이상이거나 탈출 조 직의 크기가 $1 \sim 2 \mathrm{~cm}^{2}$ 이면 경유양동 접근법과 최소 개두술의 복합 접근법을 통해 수술하도록 한다. 탈출 조직이 $2 \mathrm{~cm}^{2}$ 이 상인 경우에는 중두개와 접근법을 통한 재건을 권하고 있다. 본 증례는 $1 \mathrm{~cm}$ 이상의 골결손이 있었고 청력이 $60 / 30 \mathrm{~dB}$ 로 중등고도 난청 수준이었으므로 수술 후 청력 개선 가능성이 있어서 중이강 폐쇄술은 시행하지 않고 복합 접근법을 통해 수막류를 성공적으로 제거하고 청력을 보존할 수 있었다.

본 증례의 경우 수술 전 혼합성 난청 $60 \mathrm{~dB}$, 기도/골도 차: $30 \mathrm{~dB})$ 이 있었고, 수술 후 약간의 호전은 있었으나 $(50 \mathrm{~dB}$, 기도/골도 차: $20 \mathrm{~dB}$ ) 여전히 기도/골도 차가 있었는데, 이는 중두개와 결손을 보강하기 위해 시행했던 측두근 회전피판 이 상고실에서 고막 상부를 덮고 있고, 느린 상피화로 인해 비 후된 고막이 전음 과정을 방해한 효과로 생각된다.

\section{REFERENCES}

1) Gross M, Eliashar R, Weinberger G. Spontaneous meningoencephalocele of the tegmen. Otol Neurotol 2006;27(4):578-9.

2) Jeong JH, Ahn SK, Jeon SY, Park JJ, Kim JP, Park IS. Post-traumatic pseudomeningocele presenting as a cyst of external auditory canal: report of a case. Auris Nasus Larynx 2006;33(3):321-4.

3) Kapusuz Z, Özkiriş M, Okur A, Saydam L. Pseudomeningocele presenting as a cyst of the external auditory canal. J Craniofac Surg 2013;24(3):e235-7.

4) Wootten CT, Kaylie DM, Warren FM, Jackson CG. Management of brain herniation and cerebrospinal fluid leak in revision chronic ear surgery. Laryngoscope 2005;115(7):1256-61.

5) Valtonen H, Geyer C, Tarlov E, Heilman C, Poe D. Tegmental defects and cerebrospinal fluid otorrhea. ORL J Otorhinolaryngol Relat Spec 2001;63(1):46-52.

6) Brown NE, Grundfast KM, Jabre A, Megerian CA, O'Malley BW Jr, Rosenberg SI. Diagnosis and management of spontaneous cerebrospinal fluid-middle ear effusion and otorrhea. Laryngoscope 
2004;114(5):800-5.

7) Vallicioni JM, Girard N, Caces F, Braccini F, Magnan J, Chays A. Idiopathic temporal encephalocele: report of two cases. Am J Otol 1999;20(3):390-3.

8) Arìstegui M, Falcioni M, Saleh E, Taibah A, Russo A, Landolfi M, et al. Meningoencephalic herniation into the middle ear: a report of 27 cases. Laryngoscope 1995;105(5 Pt 1):512-8.

9) Ramalingam KK, Ramalingam R, SreenivasaMurthy TM, Chandrakala GR. Management of temporal bone meningo-encephalocoele. J Laryngol Otol 2008;122(11):1168-74.
10) Sanna M, Fois P, Russo A, Falcioni M. Management of meningoencephalic herniation of the temporal bone: Personal experience and literature review. Laryngoscope 2009;119(8):1579-85.

11) Souliere CR Jr, Langman AW. Combined mastoid/middle cranial fossa repair of temporal bone encephalocele. Skull Base Surg 1998; 8(4):185-9.

12) Sanna M, Sunose H, Mancini F, Russo A, Taibah A, Falcioni M. Problems and solutions in mastoid surgery. In: Sanna H, Sunose H, editors. Middle Ear and Mastoid Microsurgery. 2nd ed. New York: Thieme;2012. p.444-59. 